\title{
Protocol
}

\section{Observation of Fluorescent Proteins in Fixed Cells}

\author{
Richard Behringer, Marina Gertsenstein, Kristina Vintersten Nagy, and Andras Nagy
}

Fluorescent proteins (FPs) are popular reporters available for gene expression detection and determination of cellular identities in the mouse. This protocol can be used to detect green fluorescent protein spectral variants and proteins labeled with the fusion tag dsRed in fixed cells.

MATERIALS

It is essential that you consult the appropriate Material Safety Data Sheets and your institution's Environmental Health and Safety Office for proper handling of equipment and hazardous material used in this protocol.

Reagents

Cell culture

Mounting medium (Molecular Probes Inc., ProLong Antifade Kit, P-7481)

Paraformaldehyde (pH 7.4, 2\% in PBS)

Equipment

Coverslips, prepared sterile (coating might be necessary for cell attachment)

Microscope equipped with FP visualization

Microscope slides

Whatman filter paper

1. Place a coverslip onto a tissue culture plate, and plate the cells on the coverslip.

2. Grow the cells for desired confluence or length of time.

3. Fix the cells in 2\% paraformaldehyde in PBS (pH 7.4) for $15 \mathrm{~min}$ at room temperature.

Do not fix in methanol or acetic acid because organic solvents destroy the light emission of some FPs.

4. Rinse the cells in $4 \mathrm{~mL}$ of PBS ( $\mathrm{pH} 7.4$ ), and then quickly wash the coverslips in $2 \mathrm{~mL}$ of PBS (pH 7.4) twice for $5 \mathrm{~min}$ at room temperature.

5. Place $10 \mu \mathrm{L}$ of mounting medium onto the middle of a glass microscopy slide.

6. Blot the edges of the coverslip gently against a piece of filter paper to remove excessive PBS.

From the Manipulating the Mouse Embryo collection, edited by Richard Behringer, Marina Gertsenstein, Kristina Vintersten Nagy, and Andras Nagy.

(c) 2019 Cold Spring Harbor Laboratory Press

Cite this protocol as Cold Spring Harb Protoc; doi:10.1101/pdb.prot092775 
R. Behringer et al.

7. Place the coverslip with the attached cells facing down onto the mounting medium.

8. Observe the fluorescence.

\section{RELATED INFORMATION}

For additional advice, see Protocol: Observation of Fluorescent Proteins in Living Cells (Behringer et al. 2019).

\section{REFERENCES}

Behringer R, Gertsenstein M, Vintersten Nagy K, Nagy A. 2019. Observation of fluorescent proteins in living cells. Cold Spring Harb Protoc doi: 10.1101/pdb.prot092767. 


\section{Observation of Fluorescent Proteins in Fixed Cells}

Richard Behringer, Marina Gertsenstein, Kristina Vintersten Nagy and Andras Nagy

Cold Spring Harb Protoc; doi: 10.1101/pdb.prot092775

\begin{tabular}{|c|c|}
\hline $\begin{array}{r}\text { Email Alerting } \\
\text { Service }\end{array}$ & Receive free email alerts when new articles cite this article - click here. \\
\hline $\begin{array}{l}\text { Subject } \\
\text { Categories }\end{array}$ & $\begin{array}{l}\text { Browse articles on similar topics from Cold Spring Harbor Protocols. } \\
\text { Cell Biology, general (1382 articles) } \\
\text { Cell Imaging (525 articles) } \\
\text { Fluorescence ( } 517 \text { articles) } \\
\text { Fluorescent Proteins ( } 259 \text { articles) } \\
\text { Visualization (524 articles) } \\
\text { Visualization of Proteins (107 articles) }\end{array}$ \\
\hline
\end{tabular}

